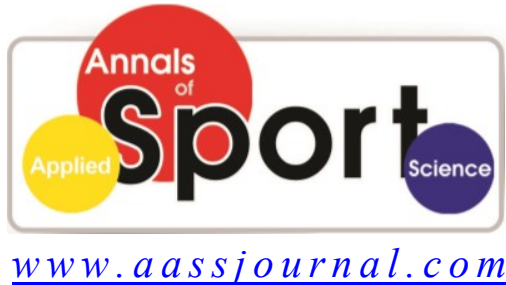

ISSN (Online): $2322-4479$

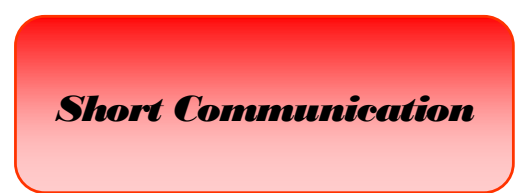

Received: $20 / 02 / 2014$ Accepted: 12/07/2014

\title{
Desire of Athlete and Non-athlete Students to Drugs Use
}

\section{${ }^{1}$ Saadi Sami*, ${ }^{1}$ Sadigh Mahmoudi, ${ }^{1}$ Naseh Karimiani}

1. Department of Physical Education and Sport Science, Marivan Branch, Islamic Azad University, Marivan, Iran.

\begin{abstract}
The purpose of this study was to evaluate and compare athlete and non-athlete students' tendency to drug use. 240 undergraduate students of University of Kurdistan with ages ranging from 19 to 23 years who had the experience of regular exercise $(n=120)$ and non-athlete ones $(n=120)$ were selected as the sample. Relapse Prediction Scale (RPS) was used for data collection. To analyze data, descriptive statistics (mean and standard deviation) and inferential statistics (independent $\mathrm{t}$ test) were used at a significant level of $\mathrm{p}<0.05$. All data were analyzed using SPSS. Study findings showed that there is a significant ( $p=0.001$ and $p=0.004$, respectively) difference between athlete and non-athlete students in both desire $(15.7 \pm 1.3$ vs $28.1 \pm 2.0)$ and temptation $(18.1 \pm 0.8$ vs $30.4 \pm 1.5$ ) to drugs abuse as athlete student had less both desire and temptation to drugs abuse than non-athlete. It is possible that engagement in sport activities have deterrent effect from some abnormal behavior such as drugs use.
\end{abstract}

Key Words: Athlete, Non-athlete, Drugs Use.

Corresponding Author:

Saadi Sami

E-mail: tabough@yahoo.com 


\section{INTRODUCTION}

Many distortion such as drug addiction are the fruit of cognitive factors and the belief system of individuals (1). Addiction is one of the fundamental problems of human societies- a problem that has destroyed the lives of millions of people and caused the national capital to be spent on fighting against addiction and treating its injuries and damages. Every day, more number of individuals resort to drug abuse and suffer its physical, psychological, cultural, familial, economic, and social consequences. Due cultural reasons, some myths, and special geographical conditions (proximity to the largest producer of drugs), conditions is more provided for Iranian youth to resort to addiction. In addition to serious health damages such as the risk of contagious infectious diseases such as HIV and hepatitis, addiction can cause many social and economic problems including increased drugrelated offenses such as theft, poverty, beggary, and loss of major material capital of countries (2). Many studies have been conducted on the causes of addiction and the relapse after treatment from a psychological perspective. One of the factors of addiction that has been frequently mentioned in previous studies is stress (3). Stress sometimes refers to an event or situation which has devastating effects on organisms (stressor) and sometimes it means the psychological tension caused by such events and situations (4). Stress is now considered an inevitable part of human life. Studies on stress emphasize the point that what that puts behavioral health at risk is not stress itself but it is the way a person evaluate stress and cope with (5). Therefore, if coping attempts are effective, competent, and adaptive, stress would put less pressure on individuals and responses to it can reduce its negative consequences. By contrast, if the coping style or pattern is maladaptive and insufficient, it not only inhibits stress but also this reaction becomes a source of pressure and exacerbates the conditions. Ability of effective coping can reduce the present and future stresses and psychopathological symptoms (6). Sports programs is one of the most prominent models of intervention in the treatment of addiction, unwillingness, and prevention of relapse. Exercise strengthens individuals for coping with internal and external pressures, achieving happiness, and escaping from the negative emotional feelings. Van Rensburg et al. (2009) stated that exercise should be considered as an effective nonmedical means of preventing individuals from smoking (7). Dishman et al. (2006) asserted that the mechanism responsible for inducing the beneficial effects of exercise on reluctance to addiction are vague. It has been shown that exercise has many similarities to smoking in stimulating the central nervous system and biological neurological processes of the brain (8). The results of a study conducted by Janas Van Rensburg and Taylor (2008) showed that exercise reduces the tendency of people to smoking (9). Katomeri (2009) reported that walking on a treadmill has a rapid and positive effect on people's reluctance to smoking (10). Daniel, Cropley, and FifeSchaw (2007) observed a significant reduction in symptoms of drug quit and tendency to smoking during and after exercise (11). According to previous studies, the question arises is that why exercise has such influence even in the short term? Given Iran is located on the way of one of the most important routes for transport of drugs and due to several problems of students including their despair and hopelessness about future and job, boring environment of dormitories, and lack of adequate recreational facilities in universities, addiction to drugs and its persistence and relapse is prevalent among university students. Therefore, exercise programs for reducing the tendency of individuals to drug use seem to be a top priority for authorities and officials of 
universities. The present study aims to evaluate and compare athlete and non-athlete students in terms of tendency to drug addiction.

\section{MATERIALS AND METHODS}

Participants. 240 undergraduate students of University of Kurdistan with ages ranging from 19 to 23 years who had the experience of regular exercise $(n=120)$ and non-athlete ones $(n=120)$ were selected as the sample.

Tools. Relapse Prediction Scale (RPS) was used to evaluate the propensity to drugs abuse. This questionnaire consists of two subscales of 47 items and each item corresponds a situation in which the subject should imagine himself and answer two subitems; intensity of strength of propensity in a certain situation and the possibility of taking in that situation. In order to confirm the reliability of this questionnaire, it was tested on a sample of 45 people with addiction to drugs. Cronbach's alpha coefficient for the first part of the questionnaire (propensity to drugs use) and the second part (possibility of taking drugs) was obtained $58 \%$ and $68 \%$, respectively (12).

Statistical Analysis. Descriptive statistics (mean and standard deviation) and inferential statistics (independent t-test) were used at a significant level of $p<0.05$. SPSS software was used for data analysis.

\section{RESULTS}

There is a significant difference between the mean scores of athlete and non-athlete students, as the mean score of athlete students is less than that of non-athlete ones in propensity to drugs abuse. Study findings showed that regular participation in sports activities has not reduced drug use, but a difference was observed between athlete and non-athlete students $(\mathrm{p}<0.01)$.

Table 1. Desire and temptation to drugs abuse in athlete and non-athlete students

\begin{tabular}{|c|c|c|c|}
\hline Variable & Group & Mean \pm SD & p \\
\hline \multirow{2}{*}{ Desire to Use } & Athlete & $15.7 \pm 1.3$ & \multirow{2}{*}{$0.001^{* *}$} \\
\hline & Non-athlete & $28.1 \pm 2.0$ & \\
\hline \multirow{2}{*}{ Temptation to use } & Athlete & $18.1 \pm 0.8$ & \multirow{2}{*}{$0.004^{* *}$} \\
\hline & Non-athlete & $30.4 \pm 1.5$ & \\
\hline
\end{tabular}

\section{DISCUSSION AND CONCLUSION}

The present study aims to evaluate and compare athlete and non-athlete students in terms of tendency to drug addiction. Study findings showed that regular participation in sports activities has not reduced drug use, but a difference was observed between athlete and non-athlete students. Studies have shown that smoking is an introduction to the drugs abuse (13). In addition, those who have never tried on smoking, alcohol, and drugs rarely get addicted to them after this course (14). Several mechanisms have been studied to show how exercise can reduce the propensity of individuals to addiction. Scans taken by fMRI suggest that parts of the brain that are stimulated by smoking symptoms become less active following the regular exercise (9). The findings of a seven-year observational study on 750 subjects in Japan revealed that increased habit of exercise is associated with reluctance to smoking and relapse of smoking increases with reduced habit of exercise (15). This result is consistent with the findings of recent studies conducted by Van Rensburg et al. (2009), Van Rensburg and Taylor (2008), Katomeri (2009), and Daniel, Cropley, and Fife-Schaw (2007), and Nagaya et al. (2007) (7, 9-11, 15). As mentioned in the introduction, stress, lack of appropriate coping skills, and poor mental 
health are the main causes of resorting to addiction. According to the obtained results, it can be concluded that exercise creates joy and increase the spirit of partnership in individuals and also leads to replacement of negative thoughts by positive ones, positive feedback from friends, increased selfconfidence, improved self-efficacy, and increased ability of coping with stresses, and increased self-esteem and mental health. Researchers believe that participation in physical activities can increase physical abilities and fitness levels. This makes changes in people's valuation and estimation of their own physical qualifications, increasing a person's sense of competence and a sense of personal satisfaction with their body and their positive perception of their body and its physical qualifications. All these will be followed by improvement of health behaviors such as adequate sleep and nutrition and experiencing social interactions with other people. Mirzaei et al. (2010) showed that mere detoxification is not enough for continuity of smoking quit and there are other factors that can cause relapse. Thus, mental health is recommended to be a top priority for addiction treatment centers. In addition, enhancement of skills for coping with relapse drug abusers is a necessary solution (16). Taremian and Mehryar (2009), in a study entitled "Effectiveness of life skills training programs for preventing drug abuse in guidance school students", showed that such trainings would increase the level of skills in the experimental group and, as a protective factor, cause reduction in drug abuse in the later years. It seems that life skills training such as participation in exercise increases self-perception, improves self-control and social skills, creates negative attitude towards drugs (17). Given the high prevalence of addiction in Iran and the health-social problems caused by, prevention and treatment of this social problem need extensive and principled planning. Due to the positive effects of exercise on various spheres of social life, development of opportunities to engage in recreational and sports activities should be a top priority for officials and authorities of other organizations and institutes. Therefore, instead of costly medical procedures and treatments, damages and infections caused by drug use can be prevented through lowcost and effective ways. In addition to the effect of exercise on protecting the youth and students against addiction, enactment of rules and regulations for limiting the accessibility to drugs, improvement of employment condition, increasing the public awareness about the consequences of addiction, and provision and expansion of opportunities for students and the youth to engage in recreational and leisure activities should be also taken into account by officials. Use or non-use of drugs in the family background of subjects and addiction of family members of subjects to other drugs can be mentioned as some constraints of the present study.

\section{REFFRENCES}

1. Denoff MS. Irrational beliefs as predictors of adolescent drug abuse and running away. Journal of clinical psychology. 1987;43(3):412-23.

2. Salehi M. Addiction and Drugs. Isfahan, Iran: Atropat Publication; 2001 [Book in Farsi].

3. Kail R, Cavanaugh J. Human Development: A Life-Span View. 6th ed: Cengage Learning; 2012.768 p.

4. Reber AS, Allen R, Reber ES. The Penguin Dictionary of Psychology. 4th ed: Penguin; 2009. 904 p.

5. Thoits PA. Social support as coping assistance. Journal of consulting and clinical psychology. 1986;54(4):416.

6. Franken IH, Hendriks VM, Haffmans P, van der Meer CW. Coping style of substance-abuse patients: Effects of anxiety and mood disorders on coping change. Journal of clinical psychology. 2001;57(3):299-306.

7. Van Rensburg KJ, Taylor A, Hodgson T, Benattayallah A. Acute exercise modulates cigarette cravings and brain activation in response to smoking-related images: an fMRI study. Psychopharmacology. 2009;203(3):589-98. 
8. Dishman RK, Berthoud HR, Booth FW, Cotman CW, Edgerton VR, Fleshner MR, et al. Neurobiology of exercise. Obesity. 2006;14(3):345-56.

9. Van Rensburg KJ, Taylor AH. The effects of acute exercise on cognitive functioning and cigarette cravings during temporary abstinence from smoking. Human Psychopharmacology: Clinical and Experimental. 2008;23(3):193-9.

10. Katomeri M. Acute Effects of Self-Paced Walking On Smoking Withdrawal and Cravings: University of Plymouth; 2009.

11. Daniel JZ, Cropley M, Fife-Schaw C. Acute exercise effects on smoking withdrawal symptoms and desire to smoke are not related to expectation. Psychopharmacology. 2007;195(1):125-9.

12. Beck AT, Wright FD, Newman CF, Liese BS. Cognitive Therapy of Substance Abuse: Guilford Publications; 2011.354 p.

13. Sullivan ML. Illegal Leisure: The Normalization of Adolescent Recreational Drug Use/Understanding and Responding to Drug Use: The Role of Qualitative Research. Contemporary Drug Problems. 2001;28(1):179-92.

14. Corbett KK. Susceptibility of youth to tobacco: a social ecological framework for prevention. Respiration Physiology. 2001;128(1):103-18.

15. Nagaya T, Yoshida H, Takahashi H, Kawai M. Cigarette Smoking Weakens Exercise Habits in Healthy Men. Nicotine \& Tobacco Research. 2007;9(10):1027-32.

16. Mirzaei T, Ravary A, Hanifi N, Miri S, Oskouie F, Mirzaei Khalil Abadi S. Addicts' Perspectives about Factors Associated with Substance Abuse Relapse. Iran Journal of Nursing. 2010;23(67):49-58 [Article in Farsi].

17. Taremian F, Mehryar A. Effectiveness of "Life Skills Training Program" In Prevention of Drug Use among Secondary School Students. Journal of Zanjan University of Medical Sciences and Health Services. 2009;16(65):77-88 [Article in Farsi]. 


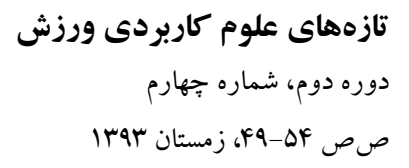

مقاله كوتاه

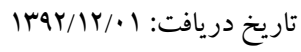

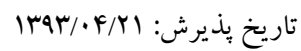

\section{تمايل دانشجويان ورزشكار و غيرورزشكار به مصرف

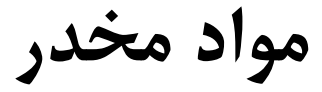

\section{'سعدى سامى'، 'صديق محمودى، 'ناصح كريميانى}

ا. مربى گروه تربيت بدنى و علوم ورزشى، دانشخاه آزاد اسلامى، واحد مريوان، مريوان، ايران.

جكيده

هدف از تحقيق حاضر بررسى و مقايسهى تمايل دانشجويان ورزشكار و غيرورزشكار به مصرف مواد مخدر بود. • • نفر از دانشجويان كارشناسى

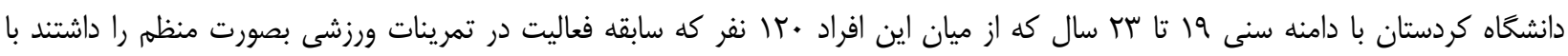

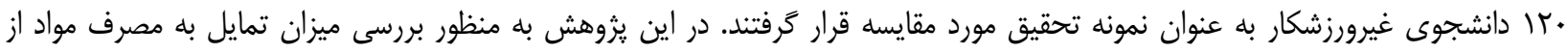

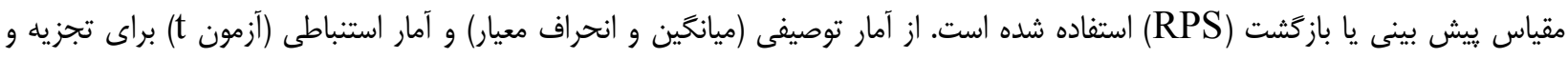

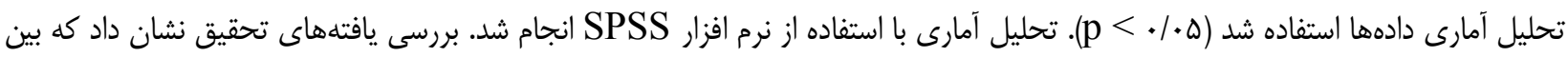

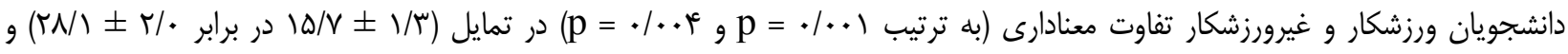

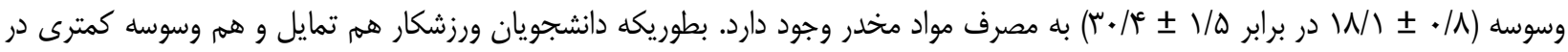
مصرف مواد مخدر نسبت به دانشجويان غيرورزشكار داشتند. به نظر مىرسد دركيرى در فعاليتهاى ورزشى بتواند اثر بازدارنده بر برخى رفتارهاى ناهنجار مانند مصرف مواد مخدر داشته باشد. وازًَان كليدى: ورزشكار، غيروزشكار، مواد مخدر. 